\title{
HSCT FOR HODGKIN LYMPHOMA
}

\author{
Alessandra Paz ${ }^{1}$, Rosane Bittencourt ${ }^{2}$, Decio Lerner ${ }^{3}$, Camila Manca $^{4}$, Mair Souza ${ }^{5}$, Otavio Baiocchi $^{6}$, \\ Philip Bachour ${ }^{7}$,Leila Pessoa de Melo ${ }^{8}$, Samir Kanaan Nabhan ${ }^{9}$
}

\begin{abstract}
1 Chief Hematologist Hematology and HSCT Service HCPA-UFRGS - 2 Responsible hematologist Autologous TCTH program at HCPA_UFRGS - 3 Chief Hematologist at the Bone Marrow Transplant Center (CEMO) - INCA - 4 Hematologist TCTH Service Base Hospital of São Jose dor Rio Preto - 5 Hematologist TCTH Hospital Amaral Carvalho de Jau - 6 Hematologist UNIFESP and Hospital Alemão Oswaldo Cruz - 7 Hematologist UNIFESP and coordinator of the Hematology Service and BMT Hospital Alemão Oswaldo Cruz - 8- Hematologist Medical Director of the Hematology Service of São Jose dos Campos 9 Hematologist Medical Supervisor of the TMO Unit oncology and hematology of the HC-UFPR Complex
\end{abstract}

Correspondence to? Alessandra Paz: alepaz@hcpa.edu.br

\begin{abstract}
Over the past few decades, advances in combination of chemotherapy and radiotherapy have significantly improved treatment for patients with classic Hodgkin's lymphoma (cHL). Currently, more than $80 \%$ of patients aged $<60$ years, and mainly with localized disease, have an enormous chance of cure. However, the prognosis of patients with primary refractory disease or those who reach a complete remission (CR) and eventually relapse remains poor. Autologous stem cell transplantation (ASCT) is the standard treatment for most patients with relapsed or refractory $\mathrm{HLc}(\mathrm{R} / \mathrm{R})$ when compared to conventional chemotherapy with a significant proportion of cured patients but $50 \%$ of them still relapse. Allogeneic transplantation is potencially the only curative therapy and since new agents such as brentuximab vedotin, nivolumab and more recently, pembrolizumab have been used before allogeneic transplant, we noticed an improved response to the procedure.
\end{abstract}

\section{INITIAL APPROACH}

After staging with the Lugano Classification, disease is, in general, classified into 3 groups: favorable localized (stages I and II, without risk factor), unfavorable localized (stages I and II with one or more risk factors) and advanced disease (stages III and IV, and some specific cases IIBX) ${ }^{[1,2,3,4,4,6,7,8,8,9]}$ The risk factors, based on characteristics of subgroups of patients with a worse prognosis in clinical trials are: (A) bulky mediastinal mass, (B) extranodal disease, (C) eritrocyte sedimentation rate and (D) $\geq 3$ nodal sites. The IPS, which stands for International Prognostic System, defines advanced disease as a risk; patients over the age of 45 years; male; stage IV; hemoglobin $<10.5 \mathrm{~g} / \mathrm{L}$; albumin $<4 \mathrm{~g} / \mathrm{L}$; leukocytes $>15 \times 10^{9} / \mathrm{L}$ and lymphocytes $<600 \times 10^{9} / \mathrm{L}$. ${ }^{[8,9,10]}$

PET-CT with FDG is recommended both at the initial evaluation and end of treatment, its result should always be reported using the Deauville score. If possible, it can be performed after 2 or 3 cycles of chemotherapy as an interim PET for early prognosis definition. Bone marrow biopsy is useful in patients without access to PET-CT at diagnosis, or special cases (such as in presence of cytopenias, for example). ${ }^{[7,9]}$ Response Assessment: PET-CT ${ }^{[8,9,10]}$ Deauville scores 1 and 2 are considered negative and scores 4 and 5 are positive (active lymphoproliferative disease). Although patients with score 3 may have a good prognosis, it is recommended that if there is a plan to reduce treatment intensity, it is considered an inadequate response for safety. ${ }^{[7,9,10]}$

We will not address first-line treatment in this article as this is not the focus of this SBTMO consensus.

\section{AUTOLOGOUS STEM CELL TRANSPLANTATION (ASCT) - IA}

Management of $\mathrm{R} / \mathrm{R} \mathrm{cHL}$ includes a mandatory new biopsy if relapse occurs $>12$ months from the end of first-line treatment and it is highly recommended if relapse is suspected $<12$ months or in primary refractory disease. ${ }^{[11]}$ 
The two immediate and simultaneous measures for $\mathrm{R} / \mathrm{R} \mathrm{CHL}$ consist of enrolling patient in a transplant center and initiating salvage chemotherapy. Chemo sensitive patients are those who achieve a response rate greater than $50 \%$, with different drug-based protocols. Patients with primary refractoriness or recurrence in less than 1 year after first-line treatment have a worse prognosis. ${ }^{[12]}$ Linch and colleagues demonstrate a clear improvement in disease-free survival (DFS) for the BEAM scheme associated with ASCT. ${ }^{[13,14,15,16,17,18]}$ PET-CT is an important prognostic factor and when negative in pre-HSCT it is associated with a higher event-free survival rate. ${ }^{[19.20]}$ The Chemo rescue more frequently used are DHAP, ESHAP,ICE with Overall Response(OR) $89 \%, 67 \%, 88 \%$ respectively. Gencitabine schemas are GDP,CVD e IGV with OR $62 \%, 70$ and $88 \%$.

Anti CD30 Brentuximabe Vedotim isolated for patients that have used 2 or more

chemo schemas have been $50 \%$ OR. Combinations with Brentuximab Vedotina (BV), monoclonal antibody anti cd30 associated with several chemotherapy schemes such as: BV-DHAP has been emerging as possibilities of rescue with very encouraging results in substitution to conventional chemotherapy thanks to high rates of complete metabolic response before transplantation $[20,21,23,24]$.

\section{MOBILIZATION}

Different methods for mobilization are employed and there is no uniformity or significant divergences between the techniques used: a) isolated application of G-CSF in standardized doses of $10 \mathrm{mg}$ and 20 $\mathrm{mg} / \mathrm{kg} /$ day. ${ }^{[25,26,27]}$ b) Cyclophosphamide + Growth Factor. Cyclophosphamide in a single dose, 1 to $2 \mathrm{~g} /$ m2 7 days before starting the application of G-CSF in the standard dose of $10 \mathrm{mg} / \mathrm{Kg} /$ day for 5 days. $[28,29,32,33] \mathrm{c})$ Plerixafor: Fixed dose of $20 \mathrm{mg}$ or $0.24 \mathrm{mg} /$ $\mathrm{Kg}$ of body weight for patients weighing $\leq 83 \mathrm{Kg}$, or $0.24 \mathrm{mg} / \mathrm{Kg}$ for patients over $83 \mathrm{~kg}$. It should be applied after 4 days of G-CSF at a dose of $10 \mathrm{mg} / \mathrm{Kg} /$ day 6 to 11 hours before apheresis, for 1 to 4 consecutive days. ${ }^{[30,31,34]}$

\section{CONDITIONING SCHEMES}

There are few studies to evaluate different conditioning schemes for ASCT in cHL. The BEAM scheme, Carmustine based, has always been the most used and many European groups emphasized its high antitumor response with acceptable toxicity. ${ }^{[27]} \mathrm{Howev}$ er, in 2015 Carmustine left the international market due to the limited availability of the alcoholic solvent necessary for its preparation. The transitory scarcity of Melphalan must also always be considered when choosing the best scheme. Table 1 show schemes that can be used with acceptable toxicity and acceptable relapse rates.

\begin{tabular}{c|c} 
SCHEME & DRUGS \\
\hline LACE35 & Lomustine/Cytarabin/Cyclophofamide/Etoposide \\
\hline LEAM36 & Lomustine/Etoposide/Cytarabin/Melphalan \\
\hline TEAM37 & Thiotepa/Etoposide/Cytarabin/Melphalan \\
\hline BUEM37 & Busulfan/Etoposide/Melphlan \\
\hline GEMBUMEL37 & Gemcitabine/Busulfan/Melphalan \\
\hline BUCYE37 & Bussulfan/Cyclophosfamide/Etoposide \\
\hline Benda-EAM37 & Bendamustin/Etoposide/Cytarabin/Melphalan \\
\hline
\end{tabular}




\section{POST-AUTOLOGOUS CONSOLIDATION OR MAINTENANCE}

Recent studies validated the risk factors for post-autologous relapse and which patients may benefit from post-transplant irradiation. ${ }^{21,22}$ These prognostic factors may characterize patients at higher risk of relapse after ASCT: primary refractory disease, relapse in the first 12 months after first-line treatment or after 12 months with extranodal disease or B symptoms, need for $>2$ rescue lines or PR/SD before transplantation. Patients with 2 or more factors have high risk replased. ${ }^{20,22,23}$ The AETHERA study, a randomized phase III study, evaluated post-autologous consolidation therapy by comparing Brentuximab vedotin versus placebo in patients at high risk of relapse or primarily refractory and after a 5 year median follow up confirmed the DFS benefit of this strategy.. ${ }^{23}$

\section{ALLOGENIC TRANSPLANTATION}

\section{Reduced intensity conditioning (RIC) - III C}

Allogeneic hematopoietic stem cell transplantation remains the only potentially curative strategy for patients with $\mathrm{CHL}$ who relapse after ASCT due to graft versus lymphoma effect. However, quality of life and mortality unrelated to relapse is still significant for patients who develop acute or chronic graft versus host disease (GVHD) and severe opportunistic infections. But role and timing for an allogeneic transplantation has been questioned in recent years with the availability of new agents. $38,39,40$

Despite the absence of randomized clinical trials, allogenic HSCT with reduced intensity conditioning (RIC) with an HLA match or haploidentical related donor, and with an unrelated donor has been a therapeutic option for the treatment of patients with relapsed post-autologous $\mathrm{LH}$ or with no response to rescue therapies. ${ }^{41}$ RIC HSCT is considered the best choice by the American society because it allows a drastic reduction in mortality related to the procedure, however, the relapse rates still remain high. ${ }^{42.43}$ The complete response before HSCT was an important differential for the increase in lymphoma-free and global survival, emphasized in the publication by Sarina and collaborators. ${ }^{44}$
In 2018, Gaudio et al. demonstrated through a multicenter retrospective study, no difference in OS (35\%) and DFS (34\%) between related and unrelated donors. Main risk factor for relapse was disease activity at time of $\mathrm{HSCT}^{45}$ The only prospective phase 2 study that evaluated low intensity allogeneic HSCT with 92 patients with LHc showed a TRM of $15 \%$ in 1 year and DFS and OS in 4 years completely different in the global population, $18 \%$ and $41 \%$ respectively, and in transplant patients with a disease classified as chemossensivel was $40 \%$ and $60 \% .{ }^{46}$

Currently, the use of monoclonal anti-CD30 antibody, Brentuximab vedotin (BV) has achieved remission rates of around $50 \%$ in patients, including those considered refractory to other rescue schemes. ${ }^{47} \mathrm{BV}$ and anti-PD1 inhibitors are increasingly used before allogeneic HSCT in order to achieve deeper responses before the procedure. ${ }^{47,48,49}$.Anti -PD1 inhibitors can be a alternative to relapsed patients after alo HSCT, but the used must be caution because GVHD risk $^{50}$

There is no consensus regarding the ideal conditioning regimen for RIC HSCT. Fludarabine with alkylating agents are the most used ones. In unrelated HSCT, the association of thymoglobulin is recommended for in vivo depletion of T lymphocytes. The vast majority of patients do not have a full match sibling or unrelated donor and, therefore, haploidentical transplantation has gained strength, especially after the use of cyclophosphamide $50 \mathrm{mg} / \mathrm{Kg} / \mathrm{day}(\mathrm{D}+3$ and $D+4)$ post-transplant for depletion of allo $T$ cells in vivo. Several retrospective studies have shown no significant differences in OS or PFS between transplant modalities with haploidentical donors when compared with matched sibling or unrelated donors. ${ }^{51,52,53,54}$. In some studies, haploidentical HSCT has also been associated with a lower rate of chronic GVHD. Main advantages of haploidentical donor are a faster search, good tolerability and a lower rate of chronic GVHD, but there are considerable disadvantages such as graft failure, acute GVHD and also a delayed immune reconstitution or risk of recurrence.In conclusion, the available evidence of haploidentical transplantation for recurrent / refractory Hodgkin's lymphoma after autologous HSCT is encouraging and this may, in fact, be an excellent option for patients without an available HLA donor. ${ }^{55}$ 
Algorithm for early referral of LH patients to the HSCT center

LHc fails first-line therapy or relapse

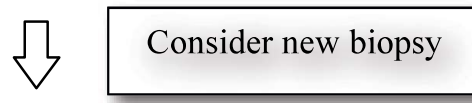

Rescue therapy + Registration at HSCT Center (if possible contact the transplant

doctor to define rescue and logistics for collection)

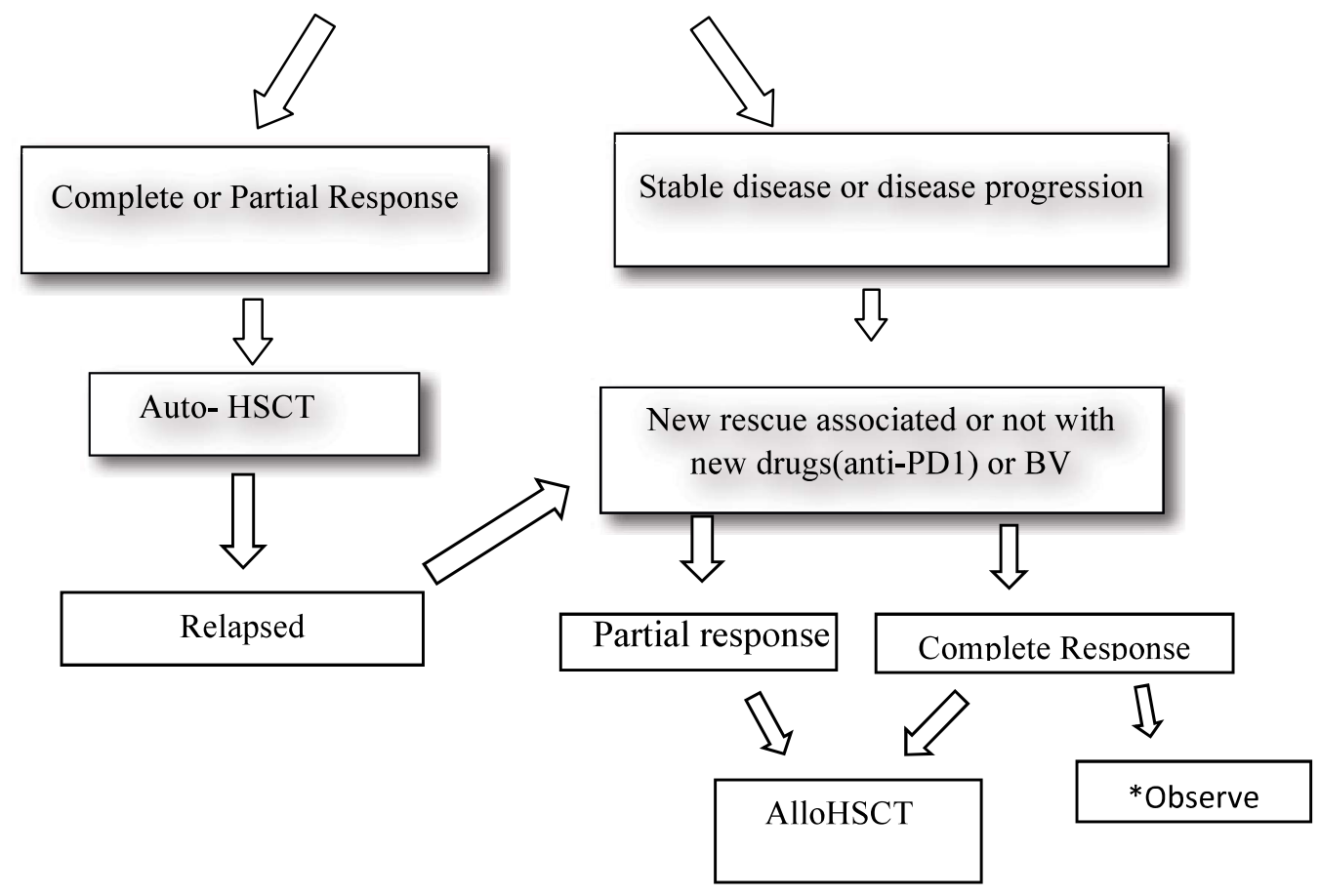

${ }^{*}$ Checkpoints inhibitors seem very effective with promising survival results, however the follow up still too short, to final decision of whether to allograft a patient relapse after auto-HSCT might rely on the risk profile of the underlying disease as well a transplantrelated risk.

\section{REFERENCES}

1.Ansell SM. Hodgkin lymphoma: A 2020 update on diagnosis, risk-stratification, and management. Am J Hematol; v. 95, n. 8, p. 978-979, 2020.

2.Linch, D.C.; Winfield, D.; Goldstone, A.H.; Moir D, H.; McMillan, A.; Chopra, R.; Milligan, D.; Hudson, G.V. Dose intensification with autologous bone-marrow transplantation in relapsed and resistant Hodgkin's disease: Results of a BNLI randomised trial. Lancet; v. 341, p. 1051-1054, 1993.
3.Schmitz, N.; Pfistner, B.; Sextro, M.; Sieber, M.; Carella, A.M.; Haenel, M.; Boissevain, F.; Zschaber, R.; Müller, P.; Kirchner, H.; et al. Aggressive conventional chemotherapy compared with high-dose chemotherapy with autologous haemopoietic stem-cell transplantation for relapsed chemosensitive Hodgkin's disease: A randomised trial. Lancet; v.359, 2065-2071, 2002.

4.Martínez, C.; Canals, C.; Sarina, B.; Alessandrino, E.P.; Karakasis, D.; Pulsoni, A.; Sica, S.; Trneny, M.; 
Snowden, J.A.; Kanfer, E.; et al. Identification of prognostic factors predicting outcome in Hodgkin's lymphoma patients relapsing after autologous stem cell transplantation. Ann. Oncol; v. 24, p. 2430-2434, 2013.

5.Sureda, A.; Canals, C.; Arranz, R.; Caballero, D.; Ribera, J.M.; Brune, M.; Passweg, J.; Martino, R.; Valcárcel, D.; Besalduch, J.; et al. Allogeneic stem cell transplantation after reduced intensity conditioning in patients with relapsed or refractory Hodgkin's lymphoma. Results of the HDR-ALLO study-a prospective clinical trial by the grupo Español de linfomas/trasplante de médula osea (GEL/TAMO) and the lymphoma working party of the European group for blood and marrow transplantation. Haematologica; v. 97, p. 310-317, 2012.

6.Jaffe ES, Banks PM, Nathwani B, Said J, Swerdlow $\mathrm{SH}$, Association of Directors of Anatomic and Surgical Pathology. Recommendations for the reporting of lymphoid neoplasms: a report from the Association of Directors of Anatomic and Surgical Pathology. The Ad Hoc Committee on reporting of lymphoid neoplasms. Hum Pathol; v. 33, n. 11, p. 1064-8, 2002.

7.Cheson BD, Fisher RI, Barrington SF, Cavalli F, Schwartz LH, Zucca E, et al. Recommendations for initial evaluation, staging, and response assessment of Hodgkin and non-Hodgkin lymphoma: the Lugano classification. $J$ Clin Oncol Off J Am Soc Clin Oncol; v. 32, n.27, p. 3059-68, 20 sep. 2014.

8.Eichenauer DA, Engert A, André M, Federico M, IIlidge $T$, Hutchings $M$, et al. Hodgkin's lymphoma: ESMO Clinical Practice Guidelines for diagnosis, treatment and follow-up. Ann Oncol Off J Eur Soc Med Oncol ESMO. 2014 Sep;25 Suppl 3:iii70-75.

9.El-Galaly TC, d'Amore F, Mylam KJ, de Nully Brown $\mathrm{P}, \mathrm{B} \varnothing \mathrm{gsted} \mathrm{M}, \mathrm{Bukh} \mathrm{A}$, et al. Routine bone marrow biopsy has little or no therapeutic consequence for positron emission tomography/computed tomography-staged treatment-naive patients with Hodgkin lymphoma. J Clin Oncol Off J Am Soc Clin Oncol; v. 30, v. 36, p. 4508-14, 2012.

10.Follows GA, Ardeshna KM, Barrington SF, Culligan DJ, Hoskin PJ, Linch D, et al. Guidelines for the first line management of classical Hodgkin lymphoma. Br J Haematol. 2014 Jul;166(1):34-49.

11.Connors JM. State-of-the-art therapeutics: Hod- gkin's lymphoma. J Clin Oncol Off J Am Soc Clin Oncol. v. 23, n.26, p. 6400-6408, 10 sep. 2005.

12.Colpo A, Hochberg E, Chen Y-B. Current status of autologous stem cell transplantation in relapsed and refractory Hodgkin's lymphoma. The Oncologist; v. 17, n. 1, p. 80-90, 2012.

13.Reece DE, Connors JM, Spinelli JJ, Barnett MJ, Fairey RN, Klingemann HG, et al. Intensive therapy with cyclophosphamide, carmustine, etoposide +/- cisplatin, and autologous bone marrow transplantation for Hodgkin's disease in first relapse after combination chemotherapy. Blood; v. 83, n. 5, p. 1133-9, 1994.

14.Bierman PJ, Lynch JC, Bociek RG, Whalen VL, Kessinger A, Vose JM, et al. The International Prognostic Factors Project score for advanced Hodgkin's disease is useful for predicting outcome of autologous hematopoietic stem cell transplantation. Ann Oncol Off J Eur Soc Med Oncol ESMO; v. 13, n. 9, 1370-7, 2002.

15.Ramzi M, Rezvani A, Dehghani M. GDP versus ESHAP Regimen in Relapsed and/or Refractory Hodgkin lymphoma: A Comparison Study. Int J Hematol-Oncol Stem Cell Res; v.9, n.1, p. 2015.

16.Kuruvilla J, Keating A, Crump M. How I treat relapsed and refractory Hodgkin lymphoma. Blood; v. 117, n.16, p. 4208-17, 2011.

17.Aparicio J, Segura A, Garcerá S, Oltra A, Santaballa $A$, Yuste $A$, et al. ESHAP is an active regimen for relapsing Hodgkin's disease. Ann Oncol Off J Eur Soc Med Oncol ESMO; v. 10, n.5, p. 1628-35, 1999.

18.Josting A, Rudolph C, Reiser M, Mapara M, Sieber $\mathrm{M}$, Kirchner $\mathrm{HH}$, et al. Time-intensified dexamethasone/cisplatin/cytarabine: an effective salvage therapy with low toxicity in patients with relapsed and refractory Hodgkin's disease. Ann Oncol Off J Eur Soc Med Oncol ESMO; v. 13, n. 10, p. 1665-70, 2002.

19.Moskowitz CH, Matasar MJ, Zelenetz AD, Nimer SD, Gerecitano J, Hamlin P, et al. Normalization of pre-ASCT, FDG-PET imaging with second-line, non-cross-resistant, chemotherapy programs improves event-free survival in patients with Hodgkin lymphoma. Blood; v.119, n.7, p. 2012.

20.Moskowitz $\mathrm{CH}$, Nademanee A, Masszi T, Agura E, Holowiecki J, Abidi MH, et al. Brentuximab vedotin as consolidation therapy after autologous stem-cell transplantation in patients with Hod- 
gkin's lymphoma at risk of relapse or progression (AETHERA): a randomised, double-blind, placebo-controlled, phase 3 trial. Lancet Lond Engl; v. 385, n. 9980, p. 1853-62, 2015.

21.Furlana,BC,"F. Matronea, M. Rupoloc, R. Cianciac, E. Zanet C, B. Montantec, E. Palazzari a, F. Navarriaa, M. Trovo d, P. Buliane, M. Spinaf, E. Coassing, M. Mascaring, A. De Paoli a, G. Franchina, M. Michieli cThe German Hodgkin Study Group risk model is useful for Hodgkin lymphoma patients receiving radiotherapy after autologous stem cell transplant, Cancer/Radiothérapie; v. 23, p. 378-384, 2019.

22.A. Nademanee, A. Sureda, P. Stiff, J. Holowiecki, M. Abidi, N.N. Hunder, M. Pecsok, M. Uttarwar, I. Purevjal, J. Sweetenham, Provisional Title: Safety Analysis of Brentuximab Vedotin From the Phase 3 AETHERA Trial in Hodgkin Lymphoma in the Posttransplant Consolidation Setting, Biology of Blood and Marrow Transplantation (2018)

23.Moskowitz $\mathrm{CH}$, Walewski J, Nademanee A, Masszi T, Agura E, Holowiecki J, Abidi MH, Chen Al, Stiff P, Viviani S, Bachanova V, Sureda A, McClendon T, Lee C, Lisano J, Sweetenham J. Fiveyear PFS from the AETHERA trial of brentuximab vedotin for Hodgkin lymphoma at high risk of progression or relapse .Blood; v. 132, n. 2, 26392642, 2018.

24.Chen R, Wang F, Zhang $H$, Chen B. Brentuximab vedotin for treatment of relapsed or refractory malignant lymphoma: results of a systematic review and meta-analysis of prospective studies. Drug Des Devel Ther. v.9,p.2277-83,2015.

25.Shpall EJ, Champlin R, Glaspy JA. Effect of CD34+ peripheral blood progenitor cell dose on hematopoietic recovery. Biol Blood Marrow Transplant J Am Soc Blood Marrow Transplant. v. 4, n.2, p.84-92, 1998.

26.Duarte FB, Prado B de PA, Vieira GMM, Costa LJ. Mobilization of hematopoietic progenitor cells for autologous transportation: consensus recommendations. Rev Assoc Medica Bras. v.62, Suppl 1, p. 10-15, 2016.

27.Gaspard MH, Maraninchi D, Stoppa AM, Gastaut JA, Michel G, Tubiana N, et al. Intensive chemotherapy with high doses of $\mathrm{BCNU}$, etoposide, cytosine arabinoside, and melphalan (BEAM) followed by autologous bone marrow transplantation: toxicity and antitumor activity in 26 patients with poor-risk malignancies. Cancer Chemother Pharmacol; v. 4, n.2, p.256-62, 1988.
28.Koç ON, Gerson SL, Cooper BW, Laughlin M, Meyerson $\mathrm{H}$, Kutteh $\mathrm{L}$, et al. Randomized crossover trial of progenitor-cell mobilization: highdose cyclophosphamide plus granulocyte colony-stimulating factor (G-CSF) versus granulocyte-macrophage colony-stimulating factor plus G-CSF. J Clin Oncol Off J Am Soc Clin Oncol; v. 18, n. 9, p.1824-1830, 2000.

29.Gertz MA, Kumar SK, Lacy MQ, Dispenzieri A, Hayman SR, Buadi FK, et al. Comparison of highdose $\mathrm{CY}$ and growth factor with growth factor alone for mobilization of stem cells for transplantation in patients with multiple myeloma. Bone Marrow Transplant; v. 43, n.8, p.619-25, 2009.

30.DiPersio JF, Stadtmauer EA, Nademanee A, Micallef IN, Stiff PJ, Kaufman JL, Maziarz RT, Hosing C, Früehauf S, Horwitz M, Cooper D, Bridger G, Calandra G; 3102 Investigators. Plerixafor and G-CSF versus placebo and G-CSF to mobilize hematopoietic stem cells for autologous stem cell transplantation in patients with multiple myeloma. Blood; v. 113, n. 23, p.5720-6, 2009.

31.De Clercq E Mozobil ${ }^{\circledR}$ (Plerixafor, AMD3100), 10 years after its approval by the US Food and Drug Administration.Antivir Chem Chemother; v. 113, n. 23, 2019.

32.D K Hiwase 1, G Bollard, S Hiwase, M Bailey, J Muirhead, A P Schwarer . Intermediate-dose CY and G-CSF more efficiently mobilize adequate numbers of PBSC for tandem autologous PBSC transplantation compared with low-dose $\mathrm{CY}$ in patients with multiple myeloma. cytotherapy; v. 9, n.6, p.2153-60, 2007.

33.Asad Bashey Michael Donohue, Lin Liu, Bridget Medina, Sue Corringham, Anita Ihasz, Ewa Carrier, Januario E Castro, Peter R Holman, Ronghui Xu, Ping Law, Edward D Ball, Thomas A Lane Peripheral blood progenitor cell mobilization with intermediate-dose cyclophosphamide, sequential granulocyte-macrophage-colony-stimulating factor and granulocyte-colony-stimulating factor, and scheduled commencement of leukapheresis in 225 patients undergoing autologous transplantation.Transfusion; v. 47, n. 11, p. 2007.

34.Mohty $M$, Duarte RF, Croockewit $S$, Hübel $K$, Kvalheim G, Russell N. The role of plerixafor in optimizing peripheral blood stem cell mobilization for autologous stem cell transplantation. Leukemia, v. 25, n. 1, p.1-6, 2011. 
35.Perz JB, Giles C, Szydlo R, O'Shea D, Sanz J, Chaidos A, et al. LACE-conditioned autologous stem cell transplantation for relapsed or refractory Hodgkin's lymphoma: treatment outcome and risk factor analysis in 67 patients from a single centre. Bone Marrow Transplant; v.39, n.1, p.41-47, 2007.

36.Colita A. LEAM vs. BEAM vs. CLV Conditioning Regimen for Autologous Stem Cell Transplantation in Malignant Lymphomas. Retrospective Comparison of Toxicity and Efficacy on $222 \mathrm{~Pa}$ tients in the First 100 Days After Transplant, On Behalf of the Romanian Society for Bone Marrow Transplantation.Front Oncol, v.9, p. 892, sep. 2019.

37.Alessandrolsidori, Anna Christofides, Giuseppe Visani. Novel regimens prior to autologous stem cell transplantation for the management of adults with relapsed/refractory non-Hodgkin lymphoma and Hodgkin lymphoma: alternatives toBEAM conditioning .Leuk Lymphoma; v. 57, n.11, p.2499-509, 2016.

38. Domingo-Domènech $E$, Sureda A. Treatment of Hodgkin Lymphoma Relapsed after Autologous Stem Cell Transplantation. J Clin Med; v. 9, n.5, p.1384, 2020.

39.Sureda A, Canals C, Arranz R, Caballero D, Ribera JM, Brune $M$, et al. Allogeneic stem cell transplantation after reduced intensity conditioning in patients with relapsed or refractory Hodgkin's lymphoma. Results of the HDR-ALLO study - a prospective clinical trial by the Grupo Español de Linfomas/Trasplante de Médula Osea (GEL/TAMO) and the Lymphoma Working Party of the European Group for Blood and Marrow Transplantation. Haematologica; v. 97, n.2, p.310-7, 2012.

40.Ansell SM. Hodgkin lymphoma: 2016 update on diagnosis, risk-stratification, and management. Am J Hematol; v. 91, n. 4, p.434-42, 2016.

41.Sureda A, Domenech E, Schmitz N, Dreger P, Lymphoma Working Party of the European Group for Stem Cell Transplantation. The role of allogeneic stem cell transplantation in Hodgkin's lymphoma. Curr Treat Options Oncol. v. 15, n. 2, p. 238-247, 2014..

42.Sarina B, Castagna L, Farina L, Patriarca F, Benedetti F, Carella AM, et al. Allogeneic transplantation improves the overall and progression-free survival of Hodgkin lymphoma patients relaps- ing after autologous transplantation: a retrospective study based on the time of HLA typing and donor availability. Blood; v. 115, n. 18, p.3671-7, 2010.

43.Gaudio F, at al Outcomes of Reduced Intensity Conditioning Allogeneic Hematopoietic Stem CellTransplantation for Hodgkin Lymphomas: A Retrospective Multicenter Experience by the ReteEmatologica Pugliese (REP).Clinical Lymphoma, Myeloma \& Leukemia,Aug 21, 2018.

44.Sureda, A.; Canals, C.; Arranz, R.; Caballero, D.; Ribera, J.M.; Brune, M.; Passweg, J.; Martino, R.; Valcárcel, D.; Besalduch, J.; et al. Allogeneic stem cell transplantation after reduced intensity conditioning in patients with relapsed or refractory Hodgkin's lymphoma. Results of the HDR-ALLO study-a prospective clinical trial by the grupo Español de linfomas/trasplante de médula osea (GEL/TAMO) and the lymphoma working party of the European group for blood and marrow transplantation. Haematologica; v. 97, p.310-317, 2012.

45.Chen $\mathrm{R}$, Wang F, Zhang $\mathrm{H}$, Chen B. Brentuximab vedotin for treatment of relapsed or refractory malignant lymphoma: results of a systematic review and meta-analysis of prospective studies. Drug Des Devel Ther; v. 9, p.2277-83, 2015.

46.Gopal AK, Ramchandren R, O'Connor OA, Berryman $\mathrm{RB}$, Advani $\mathrm{RH}$, Chen $\mathrm{R}$, et al. Safety and efficacy of brentuximab vedotin for Hodgkin lymphoma recurring after allogeneic stem cell transplantation. Blood; v. 9, p. 2012.

47.Younes, A.; Gopal, A.K.; Smith, S.E.; Ansell, S.M.; Rosenblatt, J.D.; Savage, K.J.; Ramchandren, R.; Bartlett, N.L.; Cheson, B.D.; de Vos, S.; et al. Results of a pivotal phase II study of brentuximab vedotin for patients with relapsed or refractory Hodgkin's lymphoma. J. Clin. Oncol; v. 30, p.5608, 2012.

48.Chen, R.; Zinzani, P.L.; Fanale, M.A.; Armand, P.; Johnson, N.A.; Brice, P.; Radford, J.; Ribrag, V.; Molin, D.; Vassilakopoulos, T.P.; et al. Phase II study of the e_cacy and safety of pembrolizumab for relapsed/refractory classic Hodgkin lymphoma. J. Clin. Oncol; v. 35, p.2125-2132, 2017.

49.Anderlini P, Saliba R, Acholonu S, Giralt SA, Andersson $B$, Ueno NT, et al. Fludarabine-melphalan as a preparative regimen for reduced-intensity conditioning allogeneic stem cell transplantation in relapsed and refractory Hodgkin's 
lymphoma: the updated M.D. Anderson Cancer Center experience. Haematologica; v. 93, n. 2, p. 257-64,. 2008.

50.Charles Herbaux, Jordan Gauthier, Pauline Brice, Elodie Drumez, Loic Ysebaert, Hélène Doyen,Luc Fornecker, Krimo Bouabdallah, Guillaume Manson, Hervé Ghesquières, Reza Tabrizi, Eric Hermet, Julien Lazarovici,Anne Thiebaut-Bertrand, Adrien Chauchet, Hélène Demarquette,Eileen Boyle, Roch Houot, Ibrahim Yakoub-Agha, and Franck Morschhauser. Efficacy and Tolerability of Nivolumab after Allogeneic Transplantation for Relapsed Hodgkin's Lymphoma. Blood; v. 129, n.18, p.2471-2478, 2017.

51.Martinez C, Gayoso J, Canals C, et al. Post-transplantation cyclophosphamide-based haploidentical transplantation as alternative to matched sibling or unrelated donor transplantation for hodgkin lymphoma: a registry study of the Lymphoma Working Party of the European Society for Blood and Marrow Transplantation. $J$ Clin Oncol; v. 35, p.3425-3432, 2017.
52.Raiola A, Dominietto A, Varaldo R, et al. Unmanipulated haploidentical BMT following non-myeloablative conditioning and post-transplantation CY for advanced Hodgkin's lymphoma. Bone Marrow Transplant; v. 49, p.190-194, 2014.

53.Kanate AS, Mussetti A, Kharfan-Dabaja MA, et al. Reduced-intensity transplantation for lymphomas using haploidentical related donors vs HLAmatched unrelated donors. Blood; v. 127, p.938-947, 2016.

54.Ghosh N, Karmali R, Rocha V, et al. Reduced-intensity transplantation for lymphomas using haploidentical related donors versus HLAmatched sibling donors: a Center for International Blood and Marrow Transplant Research analysis. J Clin Oncol; v. 34, p.3141-3149, 2016.

55.Ahmed S,Kanakry JA,Ahn KW, et al. Lower graftversus-host disease and relapse risk in pos-transplant Cyclophosfamide-based haploidentical versus matched sibiling donor reduced-intensity conditioning transplant for Hodgkin Lymphoma.Biol Blood Marrow transplant; v. 25, n. 9, p.1859-1868, 2019. 